\title{
Reliability and Validity of a New Pain Measurement Tool: Pictorial Representation of Pain
}

\author{
Yeni Bir Ağrı Ölçüm Yönteminin Güvenilirliği ve Geçerliliğĭ: \\ Ağrının Resimsel Olarak Gösterimi
}

\author{
Cenker EKEN, ${ }^{1}$ Özcan ASilKAN, ${ }^{2}$ Fırat BEKTAŞ, ${ }^{1}$ Uğur BilgGE, ${ }^{3}$ Oğuz KÜÇÜKYILMAZ, ${ }^{1}$ \\ Neslihan KORKMAZ, ${ }^{1}$ Gülsüm ANKUN, ${ }^{1}$ Yıldıray ÇETE ${ }^{1}$ \\ Departments of ${ }^{1}$ Emergency Medicine, ${ }^{3}$ Biostatistics, Akdeniz University Faculty of Medicine, Antalya; \\ ${ }^{2}$ Department of Informatics, Akdeniz University, Antalya, Turkey
}

\section{SUMMARY \\ Objectives}

The aim of this study was to determine the reliability and validity of a new pain measurement tool, Pictorial Representation of Pain (PRP), in order to determine its ability to measure the intensity of pain and burden of pain for patients in Emergency Department (ED).

\section{Methods}

Pictorial Representation of Illness and Self Measure (PRISM) has been used as a tool in psychiatric interviews in order to determine the burden of an illness. With modification, a new software named PRP was developed for use in Akdeniz University Hospital ED (Antalya, Turkey). Patients presented to the ED with acute pain were enrolled into the study. Study patients were asked to rate their pain levels at 0, 1, 30, 31, 60 and 61 minutes with PRP and a verbal descriptive scale in order to determine the minimum clinically significant difference.

\section{Results}

A total of 246 patients were included into the study with mean age of $40.6 \pm 15.4$. Eighty seven (35\%) were men. The correlation coefficient between PRP scores one minute apart were 0.95 (95\% Cl: 0.94 to 0.96$), 0.95$ ( $95 \% \mathrm{Cl}: 0.93$ to 0.96$)$ and 0.98 (95\% Cl: 0.83 to 0.99$)$ at the three preset time ( $0 \mathrm{~min}, 30 \mathrm{~min}, 60 \mathrm{~min}$ ) respectively. And the overall correlation coefficient was 0.96 ( $95 \% \mathrm{Cl}: 0.96$ to 0.97$)$. The minimum clinically significant change in pain was $28.7 \mathrm{~mm}(95 \%$ Cl: 27 to 30) with a median of $28 \mathrm{~mm}$ (IQR: $23-34,95 \% \mathrm{Cl}: 26$ to 30 ).

\section{Conclusions}

PRP could be considered as a reliable and consistent tool for measuring the intensity of pain. However, further studies are needed to determine the use of PRP in measuring burden of pain.

Key words: Burden of pain; measurement; pain; pictorial representation of pain; visual analog scale.

\section{ÖZET}

\section{Amaç}

Bu çalışmanın amacı yeni bir ağrı ölçeğinin (Ağrının Resimsel Temsili) geçerliliğini ve güvenilirliğini test etmektir. Ayrıca, yeni ölçeğin ağrının yoğunluğunu ve hastanın ağrıdan ne kadar muzdarip olduğunu ölçmedeki yeterliliğini de test etmeyi amaçladık.

\section{Gereç ve Yöntem}

Pictorial Representation of IIIness and Self Measure (PRISM), psikiyatrik görüşmelerde kişinin hastalıktan ne kadar muzdarip olduğunu belirlemek için kullanılmaktadır. PRISM biraz modifiye edilerek acil serviste kullanılmak üzere yeni ağrı ölçeğini geliştirdik. Acil servise akut ağrı ile başvuran hastalar çalışmaya alındı. Çalışma hastalarından 0., 1., 30., 31., 60. ve 61'inci dakiklarda ağrılarını yeni ölçek ve sözel ağrı skalası ile işaretlemeleri istendi ki minimum klinik anlamII fark saptanabilsin.

\section{Bulgular}

Çalışmaya yaş ortalması 40.6ะ15.4 olan 246 hasta alındı. Hastaların 87'si (35\%) erkekti. Birer dakika aralıklarla yapılan işaretlemeler yeni ağrı ölçeği skorlarının 0., 30. ve 60. dakikalardaki korelasyon katsayıları sırasılyla; 0.95 (95\% Cl: 0.94 ile 0.96), 0.95 (95\% Cl: 0.93 ile 0.96) ve 0.98 (95\% Cl: 0.83 ile 0.99). Tüm zamanlardaki korelasyon katsayısı ise 0.96'ydı (95\% Cl: 0.96 ile 0.97). Ağrının azalmasında minimum klinik anlamlılık ortalama $28.7 \mathrm{~mm}$ (95\% Cl: 27 ile 30) ve ortanca olarak da $28 \mathrm{~mm}$ (IQR: 23-34, 95\% Cl: 26 ile 30) idi.

\section{Sonuç}

Yeni ağrı ölçeği ağrının yoğunluğunu ölçmede güvenilir bir araç olabilir. Ancak, yeni ağrı ölçeğinin kullanılabilmesi ve ağrının hasta üzerinde oluşturduğu etkileri ölçüp ölçemediğini belirlemek için daha fazla çalışmaya ihtiyaç vardır.

Anahtar sözcükler: Ağrının verdiği sıkıntı; ölçüm; ağrı; ağrının resimsel temsili; görsel analog skala.

\footnotetext{
Presented at the 1st Eurasian Congress on Emergency Medicine (November 5-9, 2008, Antalya, Turkey).

1. Avrasya Acil Tip Kongresi'nde sunulmuştur (5-9 Kasım 2008, Antalya).
}

Submitted (Geliş tarihi): March 12, 2011 Accepted (Kabul tarihi): March 21, 2011

Correspondence (İletişim): Cenker Eken, M.D. Akdeniz Üniversitesi Tıp Fakültesi Acil Tıp Anabilim Dalı, 07059 Antalya, Turkey 


\section{Introduction}

Pain is one of the most common presenting complaints among emergency visits. ${ }^{[1]}$ The Joint Commission on Accreditation of Healthcare Organizations (JCAHO) has stated pain assessment and management as a major service requirement for healthcare organizations. ${ }^{[2,3]}$ However, perception is complicated and affected by subjective feeling. Measurement of pain and effective pain management is still a challenge for emergency physicians.

Pain measurement has been currently used as the sixth vital sign in emergency settings. Visual analog scale (VAS), numerical rating scale (VRS), verbal rating scale and picture scales such as face pain scale have been the most commonly used tools in emergency departments to assess the intensity of pain. ${ }^{[4]}$

However, intensity of pain and suffering from pain are not the same. Suffering from an illness or burden of an illness is difficult to be measured and there is not a scale used in measuring burden of pain or patient's suffering from pain. Pictorial Representation of Illness and Self Measure (PRISM) is a novel non-verbal measurement tool that is used for determining the burden of an illness in psychiatric interviews. ${ }^{[5]}$

In the present study, we modified the PRISM scale to produce a new pain measurement tool and named it "Pictorial Representation of Pain" (PRP). We aimed to determine the reliability and the validity of PRP either as a tool for pain measurement or burden of pain.

\section{Materials and Methods}

\section{Study Design}

This was an observational cohort study conducted in November 2007 at an academic ED with an annual census of 50,000 .

\section{Study Setting and Population}

A convenience sample of patients admitted to the ED between 08:00 and 16:00 with acute pain (duration less than 24 hours) or increased intensity of pain during the last 24 hours were enrolled in the study by the research assistants. All subjects provided with a written informed consent and both local and central government ethics committees approved the study protocol.

Patients who were 18 years of age and older were included in the study. Patients with regular pain going on longer than 24 hours, those with visual problems and who refused to give consent were excluded. Only the patients admitted to the observation unit and categorized as non-urgent according to their complaints were enrolled into the study.

\section{Development of the New Scale (Pictorial Representation of Pain)}

An A4-size metal board with a fixed yellow disk, seven $\mathrm{cm}$ in diameter at the bottom right hand corner is used in PRISM. The patient is asked to imagine that the board represents his life at the moment, and the disk represents patient's "Self". Subjects are given a red disk, five $\mathrm{cm}$ in diameter, with a magnetic strip and asked to place the red disk, representing his illness, over the board to reflect the importance of his illness at that particular moment. The distance from the center of the two disks is measured in centimeters. ${ }^{[5]}$

We get the inspiration from the PRISM. As a result, we developed a new software named "Pictorial Representation of Pain". PRP was developed to be used in a desktop computer or a personal digital assistant (PDA).

As illustrated in Figure 1, PRP is composed of two circles inside a box. The circle at the upper left hand corner with red color represents the pain and the circle at the lower right corner with blue color represents the patient's "Self". The maximum distance between two circles was $100 \mathrm{~mm}$. Unlike PRISM, the red circle can be moved only in a linear direction. The patients were asked 'how is your pain now?'. Patients were then asked to move the red circle representing pain towards the blue circle representing himself with a PDA pen by asking "how is your pain now?". While the patient moved the pain circle towards the self circle, the self circle changed from blue to red. When patient ceased to move the pain circle, the PRP alive was obtained by clicking the "Tamam" ("Okay" in English ) button. The rating of PRP was performed by a PDA, Dell ${ }^{\circledR}$.

\section{Study Protocol and Measurements}

Patients were asked to rate PRP at 0, 1, 30, 31, 60 and 61 minutes. However, study subjects would be withdrawn from the study without waiting for 60 minutes if they were completely pain free or their pain had improved so much

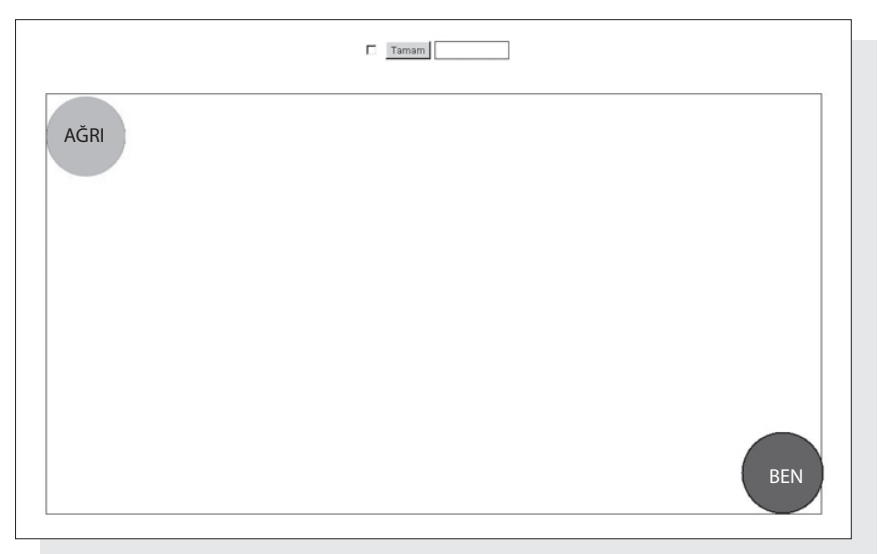

Figure 1. Layout of the PRP software. 
Table 1. Correlation between PRP ratings within 1-minute time intervals

\begin{tabular}{lccc}
\hline Time (min) & $\mathbf{N}$ & $\mathbf{R}$ & $\mathbf{9 5 \%} \mathbf{~ C l}$ \\
0 and 1 & 246 & 0.95 & $0.94-0.96$ \\
30 and 31 & 145 & 0.95 & $0.93-0.96$ \\
60 and 61 & 8 & 0.98 & $0.83-0.99$ \\
Total & 399 & 0.96 & $0.96-0.97$
\end{tabular}

that the patient could be discharged from the ED. Demographic data such as gender, age and causes of pain were also recorded.

Patients' perception of the change in pain from the last measurement was also recorded with the verbal descriptive scale as "much less pain", "a little less pain", "about the same pain", "a little more pain" and "much more pain".

\section{Statistical Analysis}

The study data was analyzed by the Med Calc 9.3.0 software. Continuous data were presented as mean with standard deviation and categorical data were presented as rate.

\section{Reliability}

Reliability of PRP was assessed by two different methods. Interclass correlation co-efficient and Bland-Altman analysis were used to assess the reliability. Bland-Altman analysis consists of calculating the mean difference between paired scores one minute apart and calculation of intervals by mul- tiplying standard deviation of mean with 1.96. KolmogorovSmirnov test is used to test for normality of the distribution.

\section{The Validity}

The minimum clinically significant difference (MCSD) for PRP were determined according to the mean changes between (1) "a little less pain" and "about the same pain" and (2) "a little more pain" and " about the same" as described in previous studies. ${ }^{[6,7]}$ Mean change in PRP scores for the categories "a little less pain" and "a little more pain" were also combined by taking the absolute value of the data of all patients in each category.

All of the hypotheses were constructed as two tailed and an alpha critical value of 0.05 was accepted as significant.

\section{Results}

A total of 246 patients were included in the study. The study subjects had a mean age of 40.6 years and 87 (\%35.3) of them were men. The distribution of pain location was as follows: 28 (11.3\%) patients with pain in extremities, 33 (13.4\%) patients with back pain, 70 (28.5\%) with headache or neck pain, 103 (41.9\%) had pain related to abdominal cavity, 5 (2\%) with chest pain and $7(2.8 \%)$ had pain in the other regions of the body.

The correlation coefficient between PRP scores one minute apart were $0.95,0.95$ and 0.98 at the three time interval $(0$ $\mathrm{min}, 30 \mathrm{~min}, 60 \mathrm{~min}$ ) respectively. The overall correlation was 0.96 (Table 1) (Figure 2).

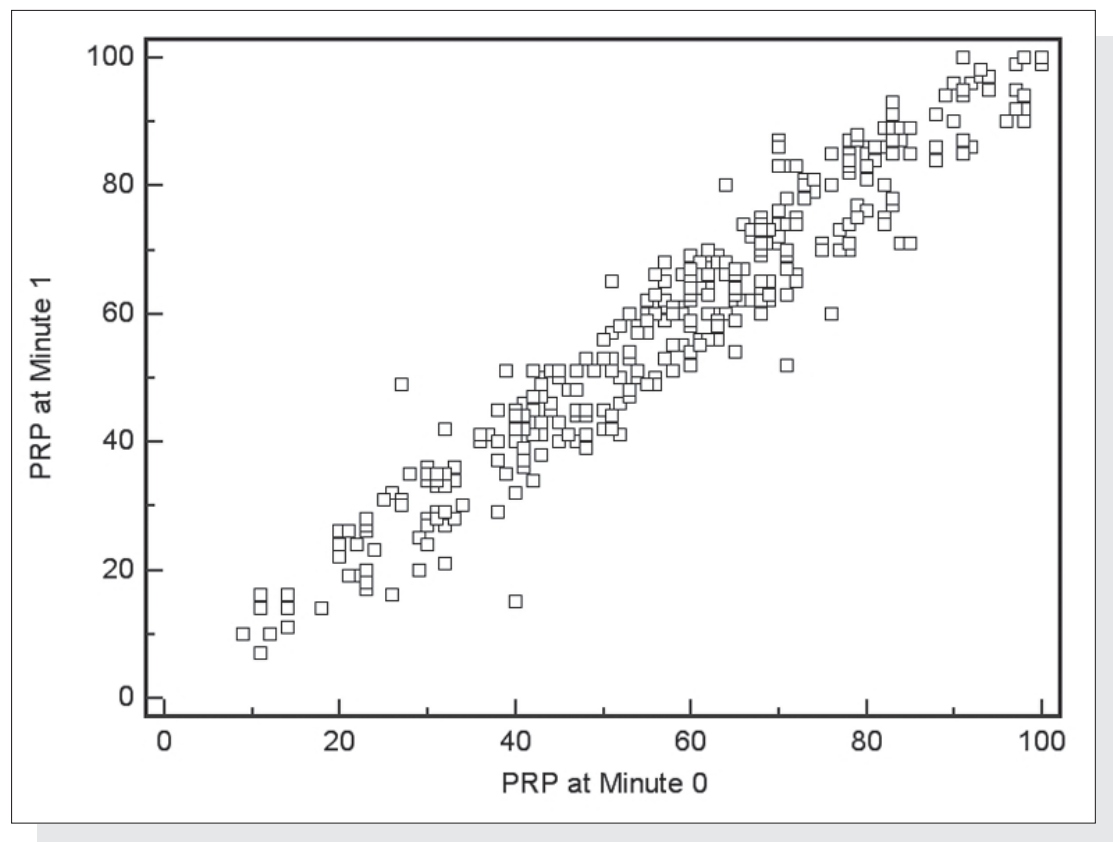

Figure 2. Relationship between PRP measurements between time 0 and time 1 (for all time points) $(n=399, r=0.96)$. 


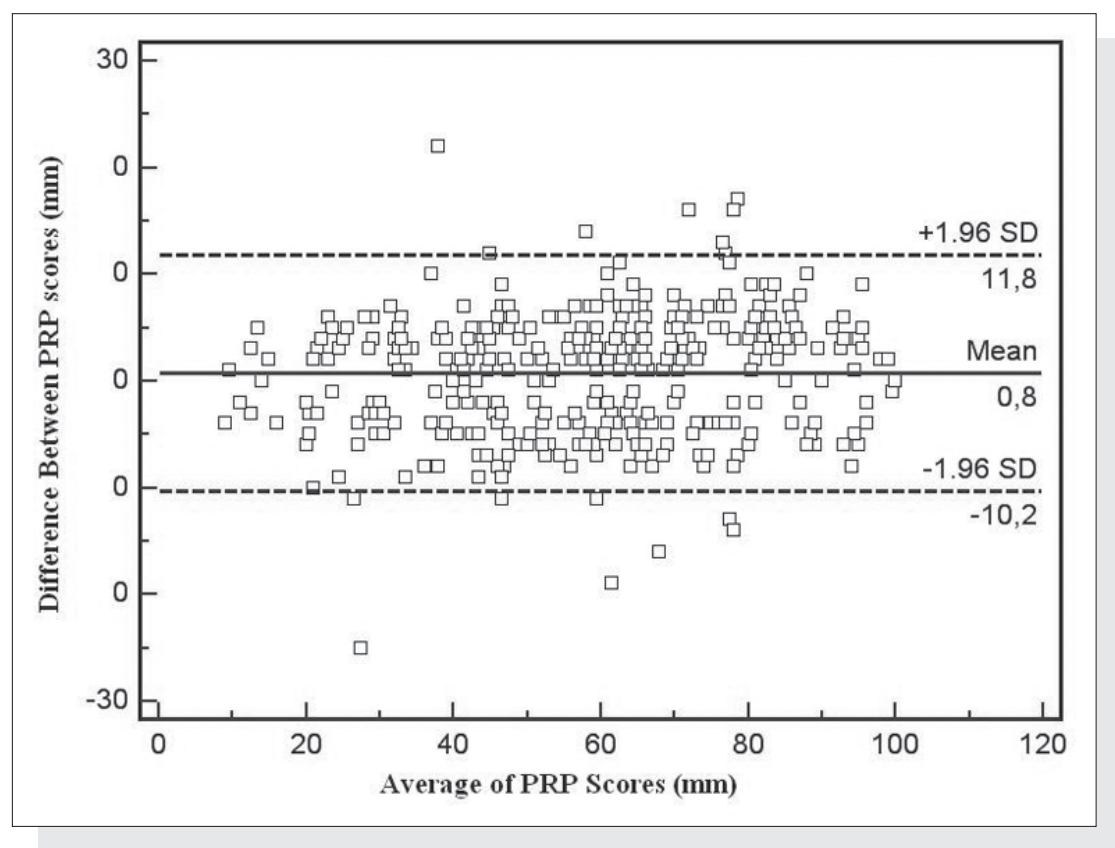

Figure 3. Bland-Altman plot displays the differences between 1-minute PRP scores. The solid line represents the mean of the differences and the dotted line indicates the interval limits as determined by mean $\pm 1.96 \times \mathrm{SD}$

Figure 3 displays the Bland-Altman analysis of mean difference of PRP score ratings over one minute time intervals plotted against the average of PRP scores. The differences between 1-minute PRP scores ranged from -25 and $22 \mathrm{~mm}$. The mean difference was $0.8 \pm 5.6 \mathrm{~mm}(95 \% \mathrm{Cl}: 0.23$ to 1.3$)$. The median difference was $2 \mathrm{~mm}$ (IQR: -4 to 4$)(95 \% \mathrm{Cl}: 1$ to 2). Ninety five percent of the ratings were between -9 and $10.5 \mathrm{~mm}, 90 \%$ were between -8 and $8 \mathrm{~mm}$.

\section{Validity}

The mean and median PRP scores increased as the pain descriptors moves from "much less" to "about the same pain" as seen in Table 2. There were 113 ratings of "a little less pain" with a mean of $-28.7 \mathrm{~mm}(95 \% \mathrm{Cl}:-27$ to -30$)$ and median of $-28 \mathrm{~mm}$ ( $95 \% \mathrm{Cl}:-26$ to -30$)$.

Table 2 displays the mean and median PRP scores for all three ratings from "much less" to "about the same pain". Because there is no "a little more pain" in the study group, the minimum significantly change in pain was $28.7 \mathrm{~mm}(95 \% \mathrm{Cl}$ : -27 to -30 ) according to the ratings of "a little less pain".

\section{Discussion}

Pain is a multidimensional feeling. ${ }^{[8]}$ Although commonly used pain scales such as VAS and NRS are reliable and easy to use, they measure the intensity of pain, not burden of pain. However, patients' satisfaction may be related to burden of pain rather than intensity of pain. The minimum clinically significant difference of VAS was reported to be between 9 $\mathrm{mm}$ and $19 \mathrm{~mm}$ in the medical literature. ${ }^{[7,9-13]}$ This minimum significant difference was reported to be $13-14 \mathrm{~mm}$ for the numeric rating scale. ${ }^{[10,14]}$ The minimum clinically significant differences both for VAS and NRS were determined by verbal descriptions, "a little more pain" and "a little less pain", which is the same in the present study. However, Lee et al. used the patients' feelings about adequate pain control rather than the verbal description scale. They reported that the

Table 2. PRP scores (in $\mathrm{mm}$ ) by verbal descriptors of change in pain

\begin{tabular}{|c|c|c|c|c|c|}
\hline Pain change & $\begin{array}{c}\text { No. of } \\
\text { comparisons }\end{array}$ & Mean \pm SD & Median (IQR) & $95 \% \mathrm{Cl}$ for mean & $95 \% \mathrm{Cl}$ for median \\
\hline Much less & 18 & $-34.8 \pm 19$ & $-38.5(-20$ to -47$)$ & -25 to -44 & -23 to -46 \\
\hline A little less & 113 & $-28.7 \pm 9$ & $-28(-23$ to -34$)$ & -27 to -30 & -26 to -30 \\
\hline About the same & 20 & $-2.6 \pm 6$ & $-3(-5$ to 0$)$ & -5 to -0.1 & -5 to 1 \\
\hline
\end{tabular}


mean decrease in VAS score was $30 \mathrm{~mm}(95 \% \mathrm{Cl}:-36$ to -23$)$ in patients denoted to have adequate pain control and -5.7 $\mathrm{mm}$ (95\% Cl: -11.2 to -0.3$)$ in the other group. Their study shows the patients' satisfaction and the clinically minimum VAS changes may differ. Although suffering from pain and intensity of pain are different things, it is difficult to differentiate them and pain rating could be affected by other factors such as mood. ${ }^{[8]}$ In another study, Bernstein et al. used Likert scale comprising of, "no relief", "a little relief", "moderate relief", "a lot of relief" and "complete relief", for evaluating pain relief in patients with acute severe pain. ${ }^{[15]}$ They found the minimum clinically significant relief as $21 \mathrm{~mm}$. These studies showed that pain relief could be measured in different ways and the MCSD might vary. It might also differ for VAS despite the equal methods used for determining MCSD. In the present study, we devised a new pain measurement tool which is modified from a psychiatric measurement tool used for establishing the patient's feelings on suffering from the illness.

Our study showed that PRP should be reliable for pain measurement. The overall interclass correlation is found to be 0.96 ( $95 \% \mathrm{Cl}: 0.96$ to 0.97$)$. Bijur et al. reported the ICC of VAS as 0.97 (95\% Cl: 0.96 to 0.98 ) and $95 \%$ of the ratings were within $16 \mathrm{~mm} \cdot{ }^{[16]}$ Galagher et al. reported an ICC of 0.99 of VAS in acute abdominal pain and $95 \%$ of the ratings were within $11 \mathrm{~mm} \cdot{ }^{[12]}$ In the present study, 95\% of the ratings were within $20 \mathrm{~mm}$. The PRP scores also decreased from "much more pain" to "much less pain" according to the verbal descriptors.

The minimum clinically significant change in PRP score was $28.7 \mathrm{~mm}$ (95\% Cl: -27 to -30$)$. This score is more than the minimum clinically significant difference in reports using VAS. Kelly et al. reported the minimum clinically significant different as $9 \mathrm{~mm}$ and Gallagher et al. reported it as $13 \mathrm{~mm}$, Gallagher et al. reported a MSCD of $16 \mathrm{~mm}$ for acute abdominal pain and Bird et al. reported a $19 \mathrm{~mm}$ MSCD for extremity trauma. However, the difference between the mean changes of "much less pain" and "a little less pain" was only $6 \mathrm{~mm}$ in PRP. Kelly et al. reported the mean difference for "a little better pain" as $8 \mathrm{~mm}$ and for "much better pain" as 25 $\mathrm{mm} .{ }^{[9]}$ Gallagher et al. reported $-15 \mathrm{~mm}$ for "a little less pain" and $-24 \mathrm{~mm}$ for "much less pain".[] In patients with acute abdominal pain -17 mm was reported for "a little less pain" and $-30 \mathrm{~mm}$ for "much less pain".[12] The high minimum clinically significant difference and the close ratings between "a little less pain" and "much less pain" need to be clarified by further studies.

There is no study in the medical literature investigating the relation between patients' discomfort or distress from pain and the intensity of pain. An interesting study conducted by Bergh et al. in geriatric patients showed that the appli- cability of VAS, NRS and graphical rating scale, decreases with advancing age and this was particularly obvious for the VAS. They also found that the agreement between verbally expressed ache or hurt and the rated experience of pain decreased with advancing age. Although PRISM measure the burden of illness in psychiatric patients, the modified form of PRISM, PRP, has to be validated by further studies.

\section{Limitations}

The findings of this study come from a sample of ED patients presented with undifferentiated pain. These findings may differ in various kinds of patient populations such as those in outpatient settings or staying in a ward. Suffering from pain may also differ according to other factors, such as duration of pain, accompanying chronic illnesses, and mood of the patient. Changes in PRP also need to be studied in relation to trauma, gender and cause of pain. VAS was found to be not affected by cause of pain, age and gender. ${ }^{[9]}$

Further studies on pain measurement tools projects should be carried out in order to determine their ability to describe the patients' burden of pain.

In the present study, we did not ask the patients whether they had the adequate pain relief or not. The clinically significant change for adequate pain relief might be an interest of this study.

\section{Conclusion}

The new pain measurement tool, Pictorial Representation of Pain, could be considered as a reliable and consistent tool for measuring the intensity of pain. However, further studies are needed to determine the ability of PRP in measuring burden of pain.

\section{Conflict of Interest}

The Author(s) declare(s) no conflict of interest related to this work.

\section{References}

1. Nawar EW, Niska RW, Xu J. National Hospital Ambulatory Medical Care Survey: 2005 emergency department summary. Adv Data 2007;386:1-32.

2. Phillips DM. JCAHO pain management standards are unveiled. Joint Commission on Accreditation of Healthcare Organizations. JAMA 2000;284:428-9.

3. Joint Commission on Accreditation of Healthcare Organizations: Setting the Standards. http://www.jointcommission.org/NR/rdonlyres/6C33FEDB-BB50-4CEE-950BA6246DA4911E/0/setting_the_standard.pdf. (Accessed November 22, 2006).

4. Todd HK. Pain assessment instruments for use in the emer- 
gency department. Emerg Med Clin N Am 2005;23:285-95.

5. Büchi S, Buddeberg C, Klaghofer R, Russi EW, Brändli O, Schlösser C, et al. Preliminary validation of PRISM (Pictorial Representation of Illness and Self Measure) - a brief method to assess suffering. Psychother Psychosom 2002;71:333-41.

6. Todd KH, Funk KG, Funk JP, Bonacci R. Clinical significance of reported changes in pain severity. Ann Emerg Med 1996;27:485-9.

7. Gallagher EJ, Liebman M, Bijur PE. Prospective validation of clinically important changes in pain severity measured on a visual analog scale. Ann Emerg Med 2001;38:633-8.

8. de C Williams AC, Davies HT, Chadury Y. Simple pain rating scales hide complex idiosyncratic meanings. Pain 2000;85:457-63.

9. Kelly AM. Does the clinically significant difference in visual analog scale pain scores vary with gender, age, or cause of pain? Acad Emerg Med 1998;5:1086-90.

10. Bijur PE, Latimer CT, Gallagher EJ. Validation of a verbally ad- ministered numerical rating scale of acute pain for use in the emergency department. Acad Emerg Med 2003;10:390-2.

11. Kelly AM. The minimum clinically significant difference in visual analogue scale pain score does not differ with severity of pain. Emerg Med J 2001;18:205-7.

12. Gallagher EJ, Bijur PE, Latimer C, Silver W. Reliability and validity of a visual analog scale for acute abdominal pain in the ED. Am J Emerg Med 2002;20:287-90.

13. Bird SB, Dickson EW. Clinically significant changes in pain along the visual analog scale. Ann Emerg Med 2001;38:639-43.

14. Kendrick DB, Strout TD. The minimum clinically significant difference in patient-assigned numeric scores for pain. Am J Emerg Med 2005;23:828-32.

15. Bergh I, Sjöström B, Odén A, Steen B. An application of pain rating scales in geriatric patients. Aging (Milano) 2000;12:380-7.

16. Bijur PE, Silver W, Gallagher EJ. Reliability of the visual analog scale for measurement of acute pain. Acad Emerg Med 2001;8:1153-7. 